Article

\title{
An Institutional Trust Indicator Based on Fuzzy Logic and Ideal Solutions
}

\author{
Juan Carlos Martín ${ }^{1, * \mathbb{C}}$, Concepción Román ${ }^{1} \mathbb{1}$ and Christian Viñán ${ }^{2}$ \\ 1 Department of Applied Economics, Institute of Tourism and Sustainable Economic Development, \\ Universidad de Las Palmas de Gran Canaria, 35017 Las Palmas de Gran Canaria, Spain; \\ concepcion.roman@ulpgc.es \\ 2 Faculty of Tourism, Universidad Técnica Particular de Loja, Loja 110107, Ecuador; csvinan@utpl.edu.ec \\ * Correspondence: jcarlos.martin@ulpgc.es
}

Received: 26 April 2020; Accepted: 13 May 2020; Published: 15 May 2020

check for updates

\begin{abstract}
The analysis of trust in the governments and the authorities has been a source of study in recent years, especially by the impact it has on facilitating economic growth and stability in developing countries. This paper analyses the institutional trust in Ecuador using data from an adapted survey of the European Social Survey. A synthetic indicator of institutional trust of Ecuadorian citizens is obtained by applying a fuzzy hybrid multi-criteria method. The analysis is based on six different dimensions, namely: (1) The Local Government (City Hall); (2) The Judicial System; (3) The Politicians; (4) Political Parties; (5) The National Parliament; and (6) the United Nations. The results obtained for the country, the nine provincial conglomerates and the gender segments show that institutional trust is not homogeneous among the provincial zones and that males trust more on institutions than females. The paper offers interesting insights to practitioners, researchers, academics, political scientists, and policymakers interested in Latin America. Suggestions for future research in the area, having in mind the existing data availability limitations, are provided.
\end{abstract}

Keywords: trust in institutions; political power; fuzzy logic; TOPSIS; Ecuadorian provinces

\section{Introduction}

Trust is a crucial intangible for all businesses and organisations that facilitate companies to do business and people to live in society. Managers must always take into account this intangible since one of the main prerogatives is to generate trust within the organisation and customers. It is a key driver for the company, not only regarding the good employees' performance but also as a demand marketing tool. Trust is a key factor in obtaining a good business reputation. There are multiple layers of a company, like, for example, the shareholders or the owners, the customers, and the employees. For this reason, business trust has multiple dimensions that are based on actions and behaviours [1].

Trust and trustworthiness are also widely studied besides economics and management disciplines, with sociological and political science being two of the most studied disciplines [2]. Since the 1950s, trust in institutions has been measured and analysed as an important component of the citizens' well-being. Thus, the importance of measuring institutional trust is based on the need to obtain a diagnosis of the organic functional behaviour of public and private institutions. If citizens are suspicious or iffy about the institutions, a mistrust of government itself is generated affecting the economic and social development [3]. Bauer [2] contends that there is a large amount of trust conceptualisations that have been proposed in theoretical and empirical research, but the conceptualisations in some of the empirical applications seem to be not well aligned with the measurement.

Institutional trust is defined here, following [4], as the confidence with which citizens assess how institutions will perform a particular action in a determined context, independent of whether 
they can monitor the action or not. Some institutions are more trusted than others, and, interestingly, "the expansion of democracy in the world has been paradoxically accompanied by a decline of political trust" [5] (p.31.) Recently, after the financial crisis, the disconnection and lack of trust of citizens towards certain institutions have been increasing. As a consequence, some norms have been introduced in public institutions requiring more transparency and efficiency in order to ameliorate the institutional trust loss [6].

The unknown nature and range of the institutional system complicates the task of measuring the degree of institutional trust. Nevertheless, many government administrations have launched projects to measure the institutional trust [7]. There are a number of issues that remain problematic in the measurement of institutional trust. First, most of the empirical quantitative research is based on a survey administered to a sample of citizens and a methodology applied to the data, and, in many cases, the representativeness of the sample or the number of institutions included in the survey is not adequate. For example, some samples are biased to some political or administrative elites like civil servants and mayors [8-10]. Second, the answers are conditioned by the institutional belief systems, which are idiosyncratic to each particular citizen and specific polities, and, normally, the survey instrument does not include questions to analyse potential patterns of subjectivity regarding different institutional support profiles [11]. Third, the difficulty of interpreting the results without subjectivity is highly influenced by the problems associated to the aggregation of different responses [12,13].

The institutional trust has been studied in Ecuador by Seligson [14] and Oller, Chavero, and Pullas [15]. In both cases, the methods and the number of institutions under analysis are different. Seligson [14] implements the Americas' Barometer using a 10-point scale to measure the Churchill item (the Winston Churchill question or item is based on the agreement or disagreement with the statement: "Even though democracy has many problems, it is better than any other form of government"; the question gets the name after that statesman's famous remark about democracy, which is the worst system of government except for all the other forms that have been tried), and a five-variable composite index (each of them measured on a 7-point scale) to measure legitimacy: (1) "To what extent do the courts guarantee a fair trial?" (2) "How much respect do you have for the political institutions of the country?" (3) "How much pride do you feel living under the political system of the country?" (4) "How much support do you have for the political system of the country?", and (5) "How much trust do you have in the police?". The author contends that 7-point scales are better suited than dichotomy or 4-5 point Likert scales to capturing subtle differences among citizens. Meanwhile, Oller, Chavero, and Pullas [15] use a triangularisation approach through the application of 31 personal interviews to Ecuadorian journalists with the following institutions: The Government, Public Institutions, Political Parties, Private Institutions, Institutions of Control and Transparency, Justice, Educational Institutions, Security Forces, Religious Institutions, and Legislative Institutions.

Our study is also different in two important aspects: (1) a new methodological approach that measures the degree of institutional trust of Ecuadorians is proposed; and (2) the institutions (Local Government, Judicial System, Politicians, Political Parties, National Parliament, and the United Nations) are based on the European Social Survey. As said, there are not many academic studies that perform a similar analysis in Ecuador, but the geographical context of the study is incidental, and not central to the main goal of the paper, which is to propose a multi-criteria fuzzy hybrid method that obtains a synthetic institutional trust. However, it should be noted that calculations of trust obtained by statistical data show that Ecuadorians, between 1998 and 2007, had very little trust in the civil institutions, especially those institutions that are shaped by popular election. This is not a surprise, as Ecuador has had 10 presidents and several coups during the period, which has increased the lack of public institutional trust (http: //noticiasdelecuador1.blogspot.com/2007/05/confianza-del-pueblo-ecuatoriano-en-el.html). Since 2007, there is a trend showing a trust increase in the Ecuadorian government and its institutions [15].

This paper has four main objectives, namely: (1) to propose a methodology based on fuzzy logic and calculate ideal solutions for institutional trust of Ecuadorians; (2) to analyse the trust on each individual institution using the ideal solutions determining whether the results are more or 
less homogeneous; (3) to analyse the institutional trust for different segments based on the different geographical areas of Ecuador and the gender; (4) to analyse the sensitivity of the results with respect to different institutions used in the analysis. In a nutshell, it can be said that the main driving forces behind this paper are the following: (1) the topic is clearly under researched in Ecuador; (2) the lack of consensus that exists among scholars to analyse an important topic as "institutional trust" of both, the number and type of institutions and the methodological approach.

Thus, the article contributes to the strand of the institutional trust literature providing more empirical evidence on a field that has not been studied in Ecuador. The study provides a number of important insights that can be used by political scientists and policymakers in order to better understand how different segments based on gender and geographical areas in Ecuador trust the institutions included in the analysis. Some recommendations of gauging institutional support of the local governments are also extracted.

\section{Institutional Trust Measurement}

Independently from the context, institutional trust is usually based on a questionnaire administered to a sample of citizens where the answer format is usually represented by a semantic Likert scale. For example, the query "How often do you trust the local government does the right thing?", can be answered as a four-point Likert scale as follows: (1) always; (2) most of the time; (3) sometimes; and (4) never [13]. It is normal that the answers' distribution is skewed towards the positive answers 1 and 2. In addition to the scale used to represent the institutional trust using a fixed set of a number of institutions, it is also normal to find in the questionnaire a single question that asks about the overall trust in public and private institutions depending on the context.

Public and private debate has also entered in the institutional trust arena as many countries are using nowadays more third-party providers for welfare services than in the past in which the provision was highly dominated by the public sector [16]. In fact, the organisational mode of welfare services could even affect the state legitimacy and, for sure, affects the institutional trust. Berg and Dahl [17] show that the public private debate does not only affect the welfare organisational system as the authors found that even the relationship between how students (age 12-17 years) perceived the fairness of their teacher and their trust in political institutions ... differs for pupils in public and private schools [16] (p.291). In addition, Ervasti et al. [18] showed that, during the Greek serious economic downturn, all institutions suffered from evident mistrust. Greece has witnessed a number of radical and violent raids, the upsurge of nationalist and racist parties, and a general disenchantment with politicians, political parties, and governmental institutions. The authors analyse the Greek institutional trust using data from five rounds of the European Social Survey and find that the level of trust of Greeks towards political institutions has diminished significantly. Linear regression models have been applied to measure the importance of each of the institutions included in the analysis. The results have been compared with ordinal probit and binomial logistic models, in order to evaluate which of the probabilistic distribution presents a better fit adjustment. Thus, the hierarchy of each individual institution in relation to the overall institutional trust can be obtained [19]. The econometric models can also include abstract institutions like traditions and other socio-economic variables used to analyse the institutional trust for different population segments [12].

Probabilistic models do not take into account the subjective nature from the answers based on semantic Likert scales, and for this reason, the introduction of a new methodological approach using the fuzzy logic is pursued. The introduction of triangular fuzzy numbers (TFNs) representing the answer format adequately approximates the subjective information provided by the respondents. The multi-criteria analysis is based on the method of ideal solutions, known by the acronym TOPSIS (technique for order preference by similarity to the ideal solution). To our knowledge, this approach has not been used to measure the intuitional trust in Ecuador. 


\section{Data}

This section describes the data obtained in Ecuador through a survey adapted from the European Social Survey. The questionnaire of round seven of the European Social Survey was used to design the instrument of the study [20]. ESS is a well-known instrument that is characterised by a broad academic participation of different European countries, allowing homogenizing the information obtained on issues that are very difficult to measure, and which have a high social interest. Adapting the survey to the Ecuadorian idiosyncrasy, this research analyses different aspects of the degree of institutional trust and other social indicators.

The survey covers different topics, such as trust in institutions, national identity, ethics, religion, religious component, the ethnic component, nationality, political commitment, welfare, health, safety, socio-political values, demographic composition, morality, social values, education, occupation, and social capital. The survey was conducted in 24 provinces of Ecuador's territory, selecting a random sample by province to represent the population over 15 years living in private households. The sample size (417 Ecuadorians) was selected to be representative of Ecuador with a 95\% of confidence level, assuming as usual the most unfavourable distribution $(p=q=0.5)$. Quotas were then prefixed according to the national proportions at the level of provinces and gender. A group of well-trained students were then in charge of administering the questionnaire telephonically according to the quotas. The telephone calls were selected at random according to the telephone list of Ecuador.

Ecuador is located in the northwest of South America, one of the smallest countries on the continent and bisected by the Equator from which comes its name. The internal political and social context of Ecuador currently reflects positions of confrontation. As the aim of this research is to measure the trust in institutions, the main questions of this module are based on six different institutions, namely: (1) Local Government; (2) The Judicial System; (3) The politicians; (4) The political parties; (5) The National Government; and (6) the United Nations. As previously said, some questions of the module are adapted to the special idiosyncrasy of Ecuador. For example, the police and the European Parliament are finally discarded from the module, and politicians and Local Government are included. In Ecuador, police function is usually taken by the military servants, and politicians describe the elites better than in the case of the EU. The format answer uses a Likert scale of 11 points (from 0 to 10) with verbal anchors at the ends, where 0 means that the person does not trust the respective institution at all, and 10 means that the person has full trust. The exact wording of the questions is: "Please, tell me on a scale of 0-10 how much you personally trust each of the institutions I read out. 0 means you do not trust an institution at all, and 10 means you have full trust". Table 1 shows the number of responses obtained in the module of institutional trust for the nine provincial zones under analysis. It can be seen that about 416 citizens answer the institutional trust module, and that local institutions have a greater representation, with the exception of the politicians (390 answers). It is difficult to assess the hindered cause behind this different response behaviour, but a conjecture about the lack of trust that Ecuadorians have on the politicians can be made. As already mentioned, between 1998 and 2007, Ecuador had already experienced more than 10 presidents, several military coups and many national strikes. For this reason, politicians are not very popular in Ecuador, and they are usually seen as one of the important causes that interfere with the institutional trust and democracy.

Walsh [21] finds that some corrupt politicians and big businessmen are the key players in the events against democracy, and that the legitimacy and the credibility decrease to the eyes of the Ecuadorian society. The similar figure of the United Nations (399 answers) does not present such a clear pattern. In this case, two significantly different forces might explain the non-response. On the one hand, respondents might have taken the decision not to make an effort, or, on the other hand, the citizens do not really know what to answer in the case of institutions that are more distant and unknown to them.

Table 2 shows the frequency table of each of the Likert scales under analysis for each institution. It can be seen that, in general, there are less citizens who fully trust the institutions (10) than those who fully exhibit a total lack of trust (0) on them. The Latinobarómetro report from 2011 notes that the 
levels of lack of trust to the main institutions of the country increase, with the political parties being one of most affected institutions [15].

Table 1. Responses by zones and institutions.

\begin{tabular}{|c|c|c|c|c|c|c|}
\hline Institutions/Zones & $\begin{array}{c}\text { Local } \\
\text { Government }\end{array}$ & $\begin{array}{l}\text { Judicial } \\
\text { System }\end{array}$ & Politicians & $\begin{array}{l}\text { Political } \\
\text { Parties }\end{array}$ & $\begin{array}{c}\text { National } \\
\text { Government }\end{array}$ & $\begin{array}{l}\text { United } \\
\text { Nations }\end{array}$ \\
\hline Zone 1 & 32 & 32 & 30 & 32 & 32 & 28 \\
\hline Zone 2 & 26 & 26 & 26 & 26 & 26 & 26 \\
\hline Zone 3 & 46 & 46 & 42 & 45 & 46 & 43 \\
\hline Zone 4 & 52 & 52 & 49 & 51 & 51 & 47 \\
\hline Zone 5 & 56 & 56 & 56 & 56 & 56 & 53 \\
\hline Zone 6 & 28 & 28 & 25 & 27 & 28 & 27 \\
\hline Zone 7 & 43 & 43 & 40 & 43 & 43 & 43 \\
\hline Zone 8 & 81 & 80 & 74 & 81 & 80 & 80 \\
\hline Zone 9 & 52 & 52 & 48 & 51 & 52 & 52 \\
\hline Total & 416 & 415 & 390 & 412 & 414 & 399 \\
\hline
\end{tabular}

Table 2. Trust total responses by institution.

\begin{tabular}{|c|c|c|c|c|c|c|}
\hline Institutions/Trust & $\begin{array}{c}\text { Local } \\
\text { Government }\end{array}$ & $\begin{array}{l}\text { Judicial } \\
\text { System }\end{array}$ & Politicians & $\begin{array}{l}\text { Political } \\
\text { Parties }\end{array}$ & $\begin{array}{c}\text { National } \\
\text { Government }\end{array}$ & $\begin{array}{l}\text { United } \\
\text { Nations }\end{array}$ \\
\hline No trust at all & 56 & 51 & 50 & 74 & 65 & 29 \\
\hline 1 & 31 & 42 & 40 & 54 & 37 & 38 \\
\hline 2 & 25 & 30 & 26 & 37 & 17 & 37 \\
\hline 3 & 25 & 23 & 21 & 26 & 21 & 23 \\
\hline 4 & 17 & 27 & 27 & 34 & 21 & 23 \\
\hline 5 & 64 & 59 & 65 & 69 & 48 & 66 \\
\hline 6 & 39 & 38 & 41 & 32 & 23 & 37 \\
\hline 7 & 55 & 50 & 39 & 31 & 40 & 44 \\
\hline 8 & 46 & 54 & 30 & 27 & 44 & 38 \\
\hline 9 & 23 & 19 & 27 & 12 & 42 & 23 \\
\hline Fully trust & 35 & 22 & 24 & 16 & 56 & 41 \\
\hline Total & 416 & 415 & 390 & 412 & 414 & 399 \\
\hline
\end{tabular}

\section{Fuzzy Logic and Ideal Solutions}

Several statistical models do not properly treat the ambiguity provided by the semantic Likert scales. Thus, the methodology proposed here to calculate the level of institutional trust is based on multi-criteria decision making MCDM studies that have been applied in different fields of the literature, especially in service quality and satisfaction. By analogy, it can be inferred that the degree of trust in institutions depends to some extent on the quality of the institutions. Under the conceptual model developed by Parasuraman, Zeithaml, and Berry [22] in the field of service quality, institutional trust is determined here by the expectations that citizens have about the policies undertaken by the institutions in relation to what they actually experience either directly or indirectly. A hybrid method that integrates the methodology of fuzzy sets with the technique of similarity to ideal solution TOPSIS is proposed to analyse the institutional trust. This method has been applied in the area of business management $[23,24]$, when a set of alternatives need to be ranked [25], and it is gaining acceptance in analysing the quality of service [26,27]. The methods are particularly suitable for solving decision problems when it is really important and necessary to obtain cardinal preferences or ranking of the alternatives available. In our case, institutional trust of a group of Ecuadorian citizens is evaluated according to two segmentation variables: the residential zone and gender.

The process of subjective assessment is inherently imprecise. On the one hand, the interaction with public institutions may or may not be direct. On the other hand, the semantic linguistic scale (from complete lack of trust (0) to complete trust (10)) that proxies the institutional trust on each institution, is, by nature, imprecise and vague. Nevertheless, in social science, the semantic scales are 
frequently used to represent preferences or judgments of respondents. This vagueness is the origin of the applicability of the theory of fuzzy logic when it comes to capturing the structure of preferences of the citizens included in the survey. Zimmermann [28] concurs that the use of fuzzy methods is an effective way to handle information that is subjective and imprecise. Herrera and Herrera-Viedma [29] add that semantic scales are popular in social science because the language is more intuitive to express the preferences and judgments.

Zadeh [30] is the founding father of the algebra of the fuzzy sets. Many of the sets found in reality have no clear boundaries that separate those elements that belong to the set. Fuzzy Logic (FL), since its foundation, has been applied not only as an adequate technique to treat the information ambiguity but an excellent theory that has been applied with other models to resolve multiple MCDM problems. For example, Yucesan et al. [31] apply jointly the fuzzy logic of interval-type 2 fuzzy numbers (trapezoidal numbers), TOPSIS, and the Best-Worst Method (BWM) to analyse the negative environmental externalities of plastic injection processes in Turkey. Papapostolou et al. [32] combine FL, with the Strengths, Weaknesses, Opportunities, and Threats (SWOT) analysis, the Analytic Hierarchy Process (AHP), and the Fuzzy Technique for Order of Preference by Similarity to Ideal Solution (Fuzzy TOPSIS) methods in order to analyse the best energy cooperation plan between countries. Ahmed et al. [33] join FL with Delphi method, Analytical Hierarchy Process (AHP), and the Fuzzy Vlse Kriterijumska Optimizacija Kompromisno Resenje (VIKOR) in order to select the best alternative for the development of special economic zones. Finally, Moslen et al. [34] integrate FL with the Best-Worst Method (BWM) to analyse the driving characteristics according to different driving situations as a way to evaluate the risky driving behaviour factors. It can be seen that FL has become an important partner for many MCDM methods.

In our case, measuring whether the trust in politicians is adequate, and denoting by $W$, the set of "features that make trust in politicians as zero", the natural research question to respond is to know why some citizens have answered this way. It can be possible that the citizens have had some direct experience observing that the proposals made on campaign are not implemented. Maybe they read something about a political corruption incident in some newspaper. The logic of this procedure recognises that there is always a positive probability of finding a citizen who answers affirmatively to this type of question. On the other hand, it seems intuitively clear that a citizen who has had an unsatisfactory contact with politicians will have less trust than those who either have not had direct contact or have experienced a friendly and professional contact. It can be then concluded then that the property to belong to a set is a measure that has varying degrees of intensity.

In this paper, the ambiguity of the institutional trust respond is proxied by the triangular fuzzy numbers, defined by a triple $\left(a_{1}, a_{2}, a_{3}\right)$ of real numbers. Each linguistic term of the Likert scale is characterised by a triangular fuzzy number in the range between 0 and 100 , where $0 \leq a_{1} \leq a_{2} \leq a_{3} \leq 100$. Table 3 shows the transformation of the default linguistic Likert scale values into the respective TFNs. It can be seen that, with the exception of the endpoints that served to anchor the verbal Likert scale, the range of all the TFNs is equal to 20 and are centred on the most likely value symmetrically. Meanwhile, the endpoints of the scale are degenerated TFNs with an inferior range of ten units.

The aggregate value of the institutional trust by each gender and region is then calculated as the average value of the TFNs. The algebra of fuzzy numbers and the close property of the TFNs show that the average is also a new TFN [35]. Thus, the crisp information matrix of 417 Ecuadorians (rows) and 6 institutions (columns) is transformed into a TFN information matrix (268 segments-6 institutions). Different methods can be used to determine whether the institutional trust in the institution $\mathrm{A}$ is greater than that of the institution B. The methods serve to clarify the information obtained through fuzzy logic converting the fuzzy numbers into real numbers-crisp information. Zhao and Govind [36] provide an overview of some of these methods like, for example, the "mean-of-maximum", the "centre-of-area", and the "alpha-cut". 
Table 3. Triangular Fuzzy Numbers (TFNs). Representatives of the Likert scale.

\begin{tabular}{cc}
\hline Linguistic Term & TFNs \\
\hline No trust at all $(0)$ & $(0,0,10)$ \\
1 & $(0,10,20)$ \\
2 & $(10,20,30)$ \\
3 & $(20,30,40)$ \\
4 & $(30,40,50)$ \\
5 & $(40,50,60)$ \\
6 & $(50,60,70)$ \\
7 & $(60,70,80)$ \\
8 & $(70,80,90)$ \\
9 & $(80,90,100)$ \\
Total trust $(10)$ & $(90,100,100)$ \\
\hline
\end{tabular}

In this paper, we clarify the information of the TFN using $v_{\widetilde{A}}$, defined as $v_{\widetilde{A}}=\left(a_{1}+2 a_{2}+a_{3}\right) / 4$. Chen [37] claims that this method is superior to others because it is simple and does not require any previous personal judgment from the analyst. The logic behind the method is expressed as the best-non-fuzzy performance or the elimination of the fuzziness [38].

The hybrid method is then developed for the clarified information matrix through the optimality concept using the best virtual alternative formed by the different institutions for all the segments of citizens-the notion of the best answer [39]. The approach is known as the TOPSIS method [40]. Thus, the positive ideal solution and the negative ideal solution are created as the reference points. The ideal positive solution is the one that takes the maximum values that each institution gets for some population segment. Meanwhile, the ideal negative solution is based on the opposite logic, so it takes the minimum values that each institution gets for some segment of citizens. The synthetic institutional trust is then calculated by the relative closeness to the positive ideal solution.

The mathematical formulation of the method can be expressed as:

$$
\begin{gathered}
\text { PIS } S_{i}=\left\{\left(\max V_{i j} \mid j \in J\right), i=1,2, \ldots, 6\right\} \\
N I S_{i}=\left\{\left(\min V_{i j} \mid j \in J\right), i=1,2, \ldots, 6\right\} \\
S_{j}^{+}=\operatorname{dist}\left(V_{j}, P I S\right)=\sqrt{\sum_{i=1}^{6}\left(V_{i j}-P I S_{i}\right)^{2}} j=1,2, \ldots, m \\
S_{j}^{-}=\operatorname{dist}\left(V_{j}, N I S\right)=\sqrt{\sum_{i=1}^{6}\left(V_{i j}-N I S_{i}\right)^{2}} j=1,2, \ldots, m \\
\text { ITSI } I_{j}=\frac{S_{j}^{-}}{S_{j}^{+}+S_{j}^{-}} \quad j=1,2, \ldots, m
\end{gathered}
$$

where $V_{i j}$ is the information clarified matrix, $\mathrm{J}$ is a set of all the population segments included in the analysis (268), PIS and NIS are the positive and negative ideal solutions, S+ and S- are the Euclidean distances between all the aggregated clarified observations and the positive and negative ideal solutions, and ITSIj is the institutional trust synthetic indicator for the segment $j$.

When a population segment is closer to the ideal solution, then the institutional trust indicator is closer to 1 . Thus, all the population segments can be classified according to this indicator in descendent order. Thus, the institutional trust for each segment of interest can be analysed with respect to all other population segments included in the analysis. For obvious reasons, the analysis will be limited to the geographical zones and gender segments. 
Once the ITSI is calculated, another remarkable variable of interest that can be calculated is the elasticity of the institutional trust indicator with respect to each institution and segment of citizens. Elasticity is an important economic concept that has the origin in physics. It serves to quantify the sensitivity (which may be positive or negative) of the institutional trust when the trust in some particular institution changes. Thus, the elasticity can be understood or defined as the percentage change in institutional trust when there is one per cent of change of trust in a particular institution. In mathematical notation, the elasticity can be calculated for each segment $j$ and each institution $i$ as:

$$
\eta_{i j}=\frac{\Delta \text { ITSI }_{j}}{\Delta \% \text { inst }_{i}}=\frac{\text { IITSI }_{j}}{\text { dinst }_{i}} \frac{\text { inst }_{i}}{\text { ITSI }_{j}}
$$

Elasticity values can help different stakeholders, such as politicians, political scientists, and policymakers in Ecuador, to determine which institutions are more or less critical in improving the overall institutional trust of the citizens in Ecuador. Knowing the sensitivity for each institution is crucial to developing policies and programmes that enhance the trust in institutions improving and consolidating as well the democracy in Ecuador. In this respect, it is quite important to see to what extent the institutional trust index is more or less elastic to local, national, or international institutions. Economic crisis and social disarrays have different impacts on institutional distrust that depend on whether the institutions are more or less grounded in the individual personal trust, trust towards proximity institutions such as Local Government, political trust (politicians and political parties), or trust towards more impersonal institutions such as the United Nations [16].

\section{Results}

Table 4 shows the negative and positive ideal solutions that are obtained from all the 268 aggregated population segments used in the analysis. The segmentation analysis is based on the different socio-economic and demographic variables that are used in the questionnaire. There are six different columns in the table. The six investigated institutions are shown in the first column. In the second and the third columns, the information about the positive ideal solution and the population segment that experiences the largest trust degree is shown. The analysis of the third column shows that the representative segment of the positive ideal solution is characterised by a sympathy degree towards some political parties (political participation), and the segment of citizens that achieves some level of alphabetisation on the Alternative Basic Education institution (ABE). (ABE institution is a mode of education for people who do not have access to the regular basic education systems. It is a system implemented to improve the education level for some population segments who do not know how to read. The fourth and fifth columns show the value and the segments of the negative ideal solution. It can be seen shown that the solution is now more represented by the segment of the population that finds their own city as an unpleasant place to live in. Finally, the sixth column shows the percentage of variation between the ideal solutions, which permits comparing the degree of homogeneity or heterogeneity that all the institutions show. It can be seen that politicians and Local Government show more heterogeneity, while the more homogeneous institution is the United Nations. A simple glance at the table shows that only the United Nations shows more acceptable trust levels for every analysed segment. The other institutions get the worst score (0-total lack of trust) for some segment.

Analysing the ideal solution values, some interesting conclusions can be extracted. First of all, the more trusted institutions are the United Nations, the Local Government, and the politicians, while the least trusted institution is the National Government. The intermediate trusted institutions are the Judicial Systems and the political parties. Ramírez [41] concludes that the Ecuadorian society in relation to Latin America before 2007 shows less trust in the political parties. According to the negative ideal solution, the United Nations is still the most trustful institution. Donoso, Montalvo, and Orcés [42], using the data from the Americas barometer, conclude that the Ecuadorians are trusting a little bit more in some public institutions than in the past years. Nevertheless, there is still an important trust gap for some institutions, especially, political parties, the National Governments, and the Judicial System. 
Table 4. Ideal solutions.

\begin{tabular}{|c|c|c|c|c|c|}
\hline Institution & PIS & Segment & NIS & Segment & $\%$ var \\
\hline $\begin{array}{c}\text { Local } \\
\text { Government }\end{array}$ & 90.00 & 'Literacy center (ABE)' & 2.5 & 'My city is a great place to live in (2).' & $3500.00 \%$ \\
\hline Justice & 85.83 & $\begin{array}{l}\text { 'List 3: Partido Sociedad Patriótica, } \\
21 \text { de Enero, PRIAN' }\end{array}$ & 2.5 & 'Occupation. NR' & $3333.33 \%$ \\
\hline Politicians & 90.00 & 'Personal Happiness (2). ' & 2.5 & ‘Occupation. NR' & $3500.00 \%$ \\
\hline Political Parties & 85.83 & $\begin{array}{l}\text { 'List 3: Partido Sociedad Patriótica, } \\
21 \text { de Enero, PRIAN' }\end{array}$ & 2.5 & 'My city is a great place to live in (2).' & $3333.33 \%$ \\
\hline $\begin{array}{l}\text { National } \\
\text { Government }\end{array}$ & 80.00 & 'Literacy center (ABE)' & 2.5 & 'My city is a great place to live in (2).' & $3100.00 \%$ \\
\hline United Nations & 91.67 & $\begin{array}{l}\text { 'List 3: Partido Sociedad Patriótica, } \\
21 \text { de Enero, PRIAN' }\end{array}$ & 10 & ‘Political Orientation (10).' & $816.67 \%$ \\
\hline
\end{tabular}

Source: Own elaboration. NR: No response.

The TOPSIS indicator is used to obtain the institutional trust synthetic indicator (ITSI) for every segment included in the dataset. Figure 1 shows the results for the Ecuadorians and the nine regional segments (zones). It can be seen that the citizens who manifest less trust towards the six institutions included in the analysis are those who reside in Napo, Orellana, and Pichincha-zone two. This fact can be explained, in part, because Napo and Orellana are Amazon provinces that have experienced a lack of opportune public intervention, and also because some of the natural resources of the region (minerals and oil) have been extracted with a very strong opposition from the autochthonous communities. The metropolitan District of Quito, the capital city of Ecuador, belongs to zone nine and shows the second minimum trust level. The capital city is usually an active node of all the important historical facts that have occurred in the democratic, social, and economic life of the country [42]. The habitants of El Oro, Loja, Zamora-zone seven, and those from Cañar, Azuay, Morona Santiago-zone six, show intermediate trust levels and are characterised by being in areas located in the Amazon and Andean regions with the exception of El Oro that belongs to the Coastal region. These areas are geographically separated from the capital city, and this might explain the lack of public intervention in the regions that also favours low political participation of the citizens. In some provinces, the last elections showed that there was no relationship between the governments and the citizens, and this fact was used by the former president Correa to support the decentralisation of the state as a strategy to facilitate and foster the political participation of the citizens [42].

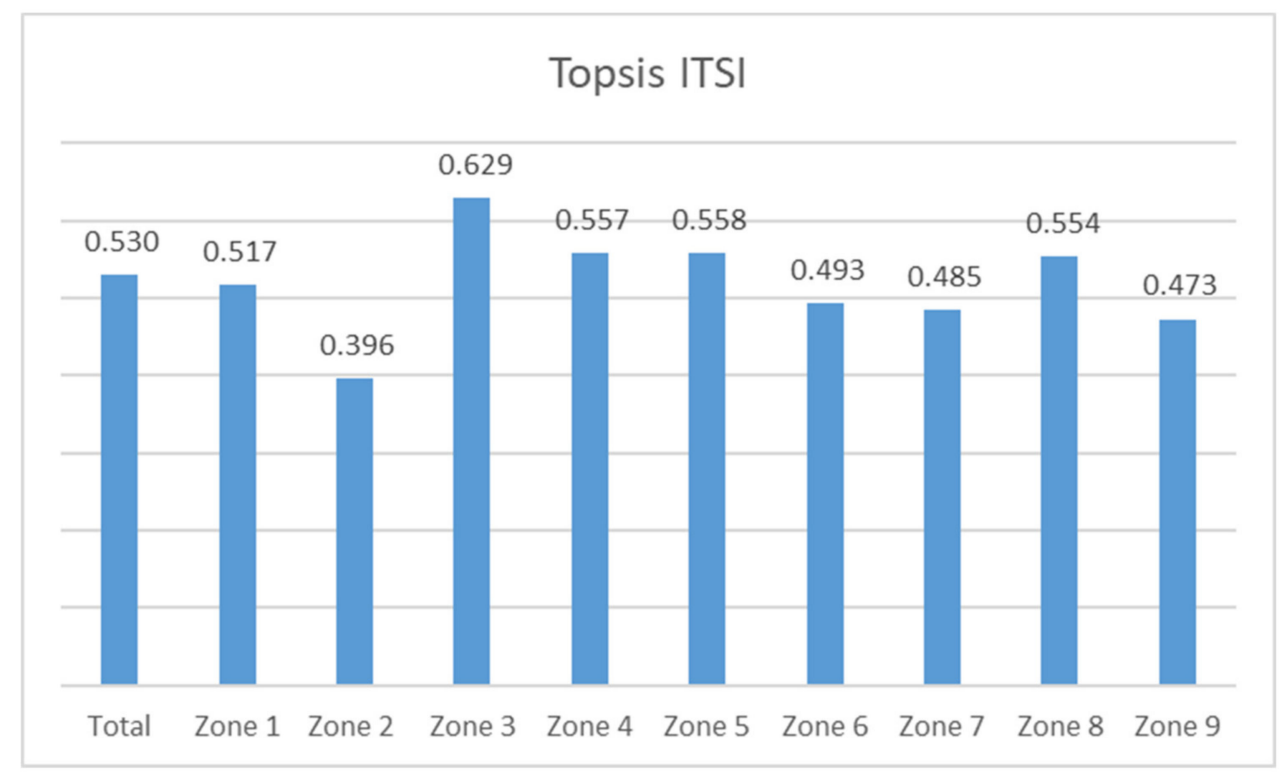

Figure 1. Institutional trust synthetic indicator (Ecuador and Regions).

In contrast, the citizens residing in Cotopaxi, Chimborazo, Tungurahua, and Pastaza-zone three, exhibit the greatest institutional trust. The result is not a surprise because, the left populism style of 
governing of former President Correa introduced the concept of "Sumak Kawsay" in the Ecuadorian Constitution of 2008 as a reference to the "Good Living" of the indigenous peoples [43]. This area is characterised by having the largest indigenous population of the country, and in the first legislative period of President Correa, the public investments in the area tried to counterbalance the existing lagged endemic public infrastructures. The results can also be explained through the support policies of the communities, since the government put emphasis on some relegated indigenous communities. The zones four (Manabí, Santo Domingo), five (Santa Elena, Guayas, Los Ríos, Bolívar, Galápagos), and eight (Cantons Guayaquil, Samborondón, Durán) are, afterwards, the regions that experience more institutional trust. Finally, it can be said that the region of residence is not only crucial to citizen participation but also to the institutional trust experienced by the citizens. Donoso, Montalvo, and Orcés [42] conclude that the citizens of the coast tend to be more involved in meetings provided by public institutions; meanwhile, the Andean region habitants show inferior levels of satisfaction with the provided services; and finally, the Amazon region habitants have more requests for public intervention.

Figure 2 shows the graph of the results of institutional trust when segmentation is performed according to gender. The results show that men experience more institutional trust than women. It is well known that in Latin America, the men participate more than women in public institutions, and participation is usually aligned with trust. This result is concordant with that obtained in the Americas Barometer by LAPOP (Latin American Public Opinion Project), where women experience less interpersonal trust than men [42].

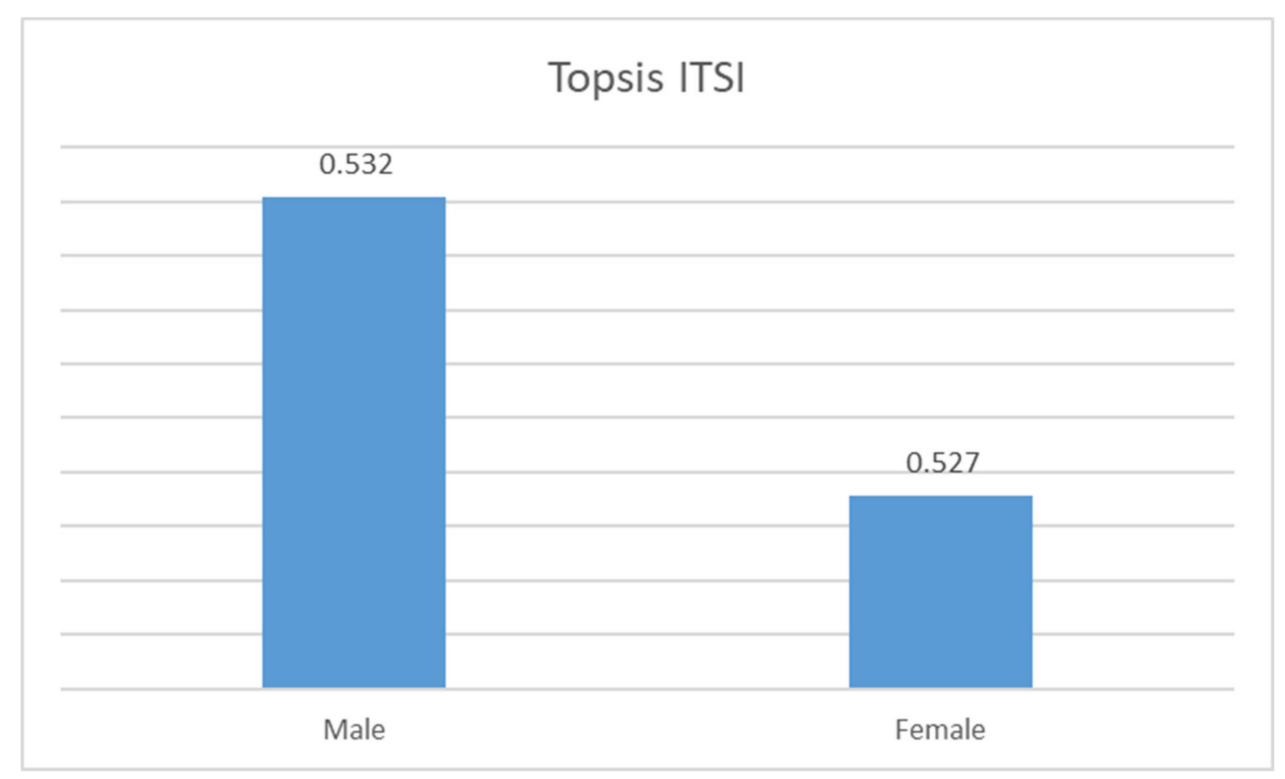

Figure 2. Institutional trust synthetic indicator. Gender.

Table 5 shows the value of the elasticity of the institutional trust synthetic indicator with respect to each institution for 10 different population segments, the Ecuadorians and the nine geographical zones of Ecuador. Overall, it can be seen that all elasticities calculated show that the degree of institutional trust is inelastic with respect to each of the institutions. However, it can also be noticed that not all the figures are equal, so, for example, the first column shows that Ecuadorians are more elastic with respect to the Local Government and less elastic with respect to the political parties. By region, analysing the particularities of each of the analysed segments, it is observed that the results do not vary much. Nevertheless, it can be seen that citizens of zones one, three, five, seven, eight, and nine are more sensitive to changes in the policies of Local Governments, while in zone four, citizens are more sensitive to changes in policies of the National Government. 
Table 5. Institutional trust elasticity by geographical zones.

\begin{tabular}{ccccccccccc}
\hline Institution & Total & Zone 1 & Zone 2 & Zone 3 & Zone 4 & Zone 5 & Zone 6 & Zone 7 & Zone 8 & Zone 9 \\
\hline Local Government & 0.1956 & 0.1930 & 0.1763 & 0.1892 & 0.1760 & 0.1865 & 0.1568 & 0.2013 & 0.2079 & 0.2205 \\
Justice & 0.1769 & 0.1797 & 0.1481 & 0.1742 & 0.1795 & 0.1692 & 0.1915 & 0.1997 & 0.1658 & 0.1582 \\
Politicians & 0.1846 & 0.1735 & 0.2465 & 0.1820 & 0.1775 & 0.1840 & 0.1966 & 0.1747 & 0.1768 & 0.2035 \\
Political Parties & 0.1471 & 0.1287 & 0.1273 & 0.1573 & 0.1387 & 0.1498 & 0.1564 & 0.1523 & 0.1514 & 0.1489 \\
National Government & 0.1762 & 0.1918 & 0.1925 & 0.1517 & 0.1814 & 0.1778 & 0.1936 & 0.1748 & 0.1602 & 0.1561 \\
United Nations & 0.1882 & 0.1821 & 0.2046 & 0.1874 & 0.1665 & 0.1829 & 0.1671 & 0.1743 & 0.2004 & 0.1982 \\
\hline
\end{tabular}

Source: Own elaboration.

\section{Conclusions}

Our analysis is based on data provided from a survey adapted from the European Social Survey to the case of Ecuador, where trust in institutions is measured by analysing six of the most important institutions that affect the daily life of citizens: (1) The Local Government; (2) The Judicial System; (3) The Politicians; (4) The Political Parties; (5) The National Government; and (6) the United Nations. The first five institutions are more related to the local sphere of the citizens and are the basic pillars of the democracies in the Western world. While, the United Nations is more related to the international sphere of the citizens, being an institution in which the main priority since 1945 has been maintaining peace in the world.

In this study, a synthetic index that measures the institutional trust of the Ecuadorians is proposed. These indices can be used to assess to what extent the Ecuadorians' institutional trust is affected by the segmenting variables used in the analysis, namely gender and geographical area. Uncertainty and vagueness of the value judgments expressed in the survey are appropriately treated by fuzzy logic using triangular fuzzy numbers.

The main conclusions extracted from the results are: (1) citizen's gender significantly affects the institutional trust; (2) at the institutional level, the United Nations is the institution that shows a higher trust level; (3) the local governments and the politicians exhibit intermediate trust levels; (4) important trust institutional differences are observed in Ecuador at geographical areas; and (5) the elasticity values for the institutional trust indicator show that the majority of the regions are more elastic to the policies of the Local Government.

While the financial crisis effects persist in the citizen's daily lives, the political parties, the politicians, the local Governments, and the National Government do not have enough resources to establish internal reforms that improve the image that citizens have of the institutions. The financial crisis and the associated corruption scandals have increased a greater disconnection and lack of trust of the citizens towards the main institutions. Therefore, the challenge of the main stakeholders is to achieve high levels of trust [15,44].

Latin America is always struggling between authoritarian and democratic systems, and public opinion over the democratic functioning as well as institutional trust is not comparable to other more stables democratic systems in the world [45]. Political instability is also mixed with very weak welfare systems, an important share of informal economy and inaccessible social security and health care system. Thus, it is not surprising that citizens have lost faith in politicians and that institutional trust is experiencing a significant regress. The lack of institutional trust in Ecuador is eroding the possibilities of democratic consolidation. A similar trend is observed in other parts of the world, especially in some southern European countries like Greece, Spain, and Portugal [28,46].

A limitation of the study is that the dataset is very limited in scope and time span as there is only one country with a static picture of a part of the year 2015. Unfortunately, there are no similar datasets to those provided by the European Social Survey. A similar attempt was promoted by the Corporación Latinobarómetro, an independent organisation based in Santiago de Chile, that funds and coordinates an annual survey conducted in 17 countries in Latin America since 1995. The project enjoys significant participation from international organisations, such as the Inter-American Development Bank (IDB), the EU, and the United Nations Development Program (UNDP). Nevertheless, the dataset 
is not freely available, and this is regrettable because extremely interesting data could be used to apply the methodology and to dynamically compare the institutional trust for a large group of Latin American countries. Thus, it would be possible to study whether the individual institutional trust at a country level can be explained by some explicative variables such as political changes, unemployment rate, and corruption scandals.

Another interesting line for future research is to include more institutions in the analysis, such as the financial institutions, the military, the police, and the media. Police trust has increased between 2009 and 2016 in ten South American countries [47], a result that, according to the authors, is probably due to the turbulent democratic past of the region. In our case, we decided not to include the question about the police as we were advised against its inclusion because police function is usually undertaken by the military servants.

Author Contributions: Conceptualisation, gathering information, writing, validation, C.V. and C.R.; Methodology, software, data treatment, writing - review and editing, original draft preparation, J.C.M. All authors discussed the results and contributed to the final manuscript. All authors have read and agreed to the published version of the manuscript.

Funding: This research received no external funding.

Conflicts of Interest: The authors declare no conflict of interest.

\section{References}

1. Hutchings, J.A.; Stenseth, N.C. Communication of Science Advice to Government. Trends Ecol. Evol. 2016, 31, 7-11. [CrossRef] [PubMed]

2. Bauer, P.C. Conceptualizing Trust and Trustworthiness. Political Concepts Working Paper Series. 2014, 61, 1-27. [CrossRef]

3. Goetze, C. The Same Old Story of Peacebuilding: Institution Building, Legitimacy and Global Governance. Int. Peacekeeping 2016, 23, 211-217. [CrossRef]

4. Gambetta, D. Can We Trust Trust? Trust: Making and Breaking Cooperative Relations; Department of Sociology, University of Oxford: Oxford, UK, 2000; Volume 13, pp. 213-237.

5. Catterberg, G.; Moreno, A. The Individual Bases of Political Trust: Trends in New and Established Democracies. Int. J. Public Opin. Res. 2005, 18, 31-48. [CrossRef]

6. Marozzi, M. Measuring trust in European public institutions. Soc. Indic. Res. 2015, 123, 879-895. [CrossRef]

7. Bouckaert, G.; Van de Walle, S.; Kampen, J.K. Potential for comparative public opinion research in public administration. Int. Rev. Adm. Sci. 2005, 71, 229-240. [CrossRef]

8. Hooghe, L. The European Commission and the Integration of Europe: Images of Governance; Cambridge University Press: Cambridge, UK, 2002.

9. Rouban, L. The Civil Service Culture and Administrative Reform. In Governance in a Changing Environment; Peters, B.G., Savoie, D., Eds.; Canadian Centre for Management Development: Montreal, QC, Canada; McGill-Queen's University Press: Kingston, UK, 1995; pp. 23-54.

10. Soós, G.; Tóka, G.; Wright, G. State of Local Democracy in Central Europe; Local Government and Public Service Reform Initiative and Open Society Institute: Budapest, Hungary, 2002.

11. Carlin, R.E. Sorting Out Support for Democracy: A Q-Method Study. Political Psychol. 2018, 39, $399-422$. [CrossRef]

12. Moreno, A. La Confianza En Las Instituciones: México En Perspectiva Comparada; Centro de Estudios Sociales y de Opinión Pública, Cámara de Diputados, LX1 Legislatura: México DF, México, 2010.

13. Wroe, A. Economic Insecurity and Political Trust in the United States. Am. Politics Res. 2016, 44, 131-163. [CrossRef]

14. Seligson, M.A. The rise of populism and the left in Latin America. J. Democr. 2007, 18, 81-95. [CrossRef]

15. Oller, M.; Chavero, P.; Pullas, T. El grado de confianza de los periodistas en las instituciones y las organizaciones de Ecuador. Ambitos Rev. Int. Comun. 2015, 28, 81-90. [CrossRef]

16. Berg, M.; Johansson, T. Building Institutional Trust Through Service Experiences-Private Versus Public Provision Matter. J. Public Adm. Res. Theory 2020, 30, 290-306. [CrossRef] 
17. Berg, M.; Dahl, V. Mechanisms of trust for different modes of welfare service provision. Public Manag. Rev. 2019, 1-22. [CrossRef]

18. Ervasti, H.; Kouvo, A.; Venetoklis, T. Social and institutional trust in times of crisis: Greece, 2002-2011. Soc. Indic. Res. 2019, 141, 1207-1231. [CrossRef]

19. Rico-Uribe, L.A.; Caballero, F.F.; Olaya, B.; Tobiasz-Adamczyk, B.; Koskinen, S.; Leonardi, M.; Haro, J.M.; Chatterji, S.; Ayuso-Mateos, J.L.; Miret, M. Loneliness, Social Networks, and Health: A Cross-Sectional Study in Three Countries. PLoS ONE 2016, 11, 0145264. [CrossRef]

20. European Social Survey. ESS Round 7 Source Questionnaire; ESS ERIC Headquarters, Centre for Comparative Social Surveys, City University London: London, UK, 2014.

21. Walsh, C.E. The Ecuadorian political irruption: Uprisings, coups, rebellions, and democracy. Nepantla Views South 2001, 2, 173-205.

22. Parasuraman, A.; Zeithaml, V.A.; Berry, L.L. A conceptual model of service quality and its implications for future research. J. Mark. 1985, 49, 41-50. [CrossRef]

23. Viswanathan, M. Understanding how product attributes influence product categorization: Development and validation of fuzzy set-based measures of gradedness in product categories. J. Mark. Res. 1999, 36, 75-95. [CrossRef]

24. Xia, X.; Wang, Z.; Gao, Y. Estimation of non-statistical uncertainty using fuzzy-set theory. Meas. Sci. Technol. 2000, 11, 430-435. [CrossRef]

25. Kannan, D.; de Sousa Jabbour, A.B.L.; Jabbour, C.J.C. Selecting green suppliers based on GSCM practices: Using fuzzy TOPSIS applied to a Brazilian electronics company. Eur. J. Oper. Res. 2014, 233, 432-447. [CrossRef]

26. Choudhury, K. Evaluating customer-perceived service quality in business management education in India: A study in topsis modeling. Asia Pac. J. Mark. Logist. 2015, 27, 208-225. [CrossRef]

27. Sun, C.C.; Lin, G.T. Using fuzzy TOPSIS method for evaluating the competitive advantages of shopping websites. Expert Syst. Appl. 2009, 36, 11764-11771. [CrossRef]

28. Zimmermann, H.J. Fuzzy Set Theory and Its Applications; Kluwer Academic Publishers: Boston, MA, USA, 1996.

29. Herrera, F.; Herrera-Viedma, E. Linguistic decision analysis steps for solving decision problems under linguistic information. Fuzzy Sets Syst. 2000, 115, 67-82. [CrossRef]

30. Zadeh, L.A. Fuzzy sets. Inf. Control 1965, 8, 338-353. [CrossRef]

31. Yucesan, M.; Mete, S.; Serin, F.; Celik, E.; Gul, M. An integrated best-worst and interval type-2 fuzzy TOPSIS methodology for green supplier selection. Mathematics 2019, 7, 182. [CrossRef]

32. Papapostolou, A.; Karakosta, C.; Apostolidis, G.; Doukas, H. An AHP-SWOT-Fuzzy TOPSIS Approach for Achieving a Cross-Border RES Cooperation. Sustainability 2020, 12, 2886. [CrossRef]

33. Ahmed, W.; Tan, Q.; Solangi, Y.A.; Ali, S. Sustainable and Special Economic Zone Selection under Fuzzy Environment: A Case of Pakistan. Symmetry 2020, 12, 242. [CrossRef]

34. Moslem, S.; Gul, M.; Farooq, D.; Celik, E.; Ghorbanzadeh, O.; Blaschke, T. An integrated approach of best-worst method (bwm) and triangular fuzzy sets for evaluating driver behavior factors related to road safety. Mathematics 2020, 8, 414. [CrossRef]

35. Buckley, J.J. Ranking alternatives. Using fuzzy numbers. Fuzzy Sets Syst. 1985, 15, 21-31. [CrossRef]

36. Zhao, R.; Govind, R. Algebraic characteristics of extended fuzzy number. Inf. Sci. 1991, 54, $103-130$. [CrossRef]

37. Chen, S.M. Evaluating weapon systems using fuzzy arithmetic operations. Fuzzy Sets Syst. 1996, 77, $265-276$. [CrossRef]

38. Kaufmann, A.; Gupta, M. Fuzzy Mathematical Models in Engineering and Management Science; Elsevier Science: New York, NY, USA, 1988.

39. Zeleny, M. Multiple Criteria Decision Making; McGraw-Hill: New York, NY, USA, 1982.

40. Hwang, C.; Yoon, K. Multiple Attribute Decision Making: Methods and Application; Springer: New York, NY, USA, 1981.

41. Ramírez, F. Participación, desconfianza política y transformación estatal. La innovación participativa en la Constitución ecuatoriana. Quito, Ecuador. 2008. (Unpublished paper).

42. Donoso, J.C.; Montalvo, D.; Orcés, D. Cultura política de la democracia en Ecuador. Consolidación Democrática En Las Américas En Tiempos Difíciles; Universidad San Francisco de Quito, Cedatos, dm Consultores, LAPOP Universidad de Vanderbilt: Quito, Ecuador, 2010. 
43. Basabe-Serrano, S.; Martínez, J. Ecuador: Cada vez menos democracia, cada vez más autoritarismo... con elecciones. Rev. Cienc. Política 2010, 34, 145-170. [CrossRef]

44. Nannestad, P. What have we learned about generalized trust, if anything? Annu. Rev. Polit. Sci. 2008, 11, 413-436. [CrossRef]

45. Lagos, M. How people view democracy: Between stability and crisis in Latin America. J. Democr. 2001, 12, 137-145. [CrossRef]

46. Torcal, M. The decline of political trust in Spain and Portugal: Economic performance or political responsiveness? Am. Behav. Sci. 2014, 58, 1542-1567. [CrossRef]

47. Macchia, L.; Plagnol, A.C. Life satisfaction and confidence in national institutions: Evidence from South America. Appl. Res. Qual. Life 2019, 14, 721-736. [CrossRef]

(C) 2020 by the authors. Licensee MDPI, Basel, Switzerland. This article is an open access article distributed under the terms and conditions of the Creative Commons Attribution (CC BY) license (http://creativecommons.org/licenses/by/4.0/). 